Article

\title{
Taxonomic and Functional Response of Millipedes (Diplopoda) to Urban Soil Disturbance in a Metropolitan Area
}

\author{
Zsolt Tóth *(1) and Elisabeth Hornung(i) \\ Department of Ecology, Institute for Biology, University of Veterinary Medicine, Rottenbiller str. 50., H-1077 \\ Budapest, Hungary; elisabeth.hornung@gmail.com \\ * Correspondence: toth.zsolt@univet.hu
}

Received: 31 October 2019; Accepted: 25 December 2019; Published: 29 December 2019

\begin{abstract}
Urbanization, as a major cause of local species extinction and biotic homogenization, drastically alters soil life. Millipedes are a key group of soil macrodetritivores and significantly influence soil quality, mainly through their essential role in nutrient cycling. Therefore, studying their taxonomic and functional responses to urban disturbance is crucial, as they contribute to the provision of several soil-related ecosystem services in cities. Differently degraded rural, urban forests and other woody patches (e.g., parks, gardens, and cemeteries) were sampled on Buda and Pest sides of the Budapest metropolitan area divided by the Danube River. We measured the most relevant physical and chemical properties of topsoil to characterize habitats. We applied an urbanization index based on vegetation cover and built-up area of the study sites to quantify urban intensity. The composition of the assemblages was determined by the division of the city along the Danube. Urbanization was associated with a reduction in species and functional richness of millipedes on both sides of Budapest. $\beta$ diversity and species turnover increased with urban intensity. Urban disturbance was the main driver in assembly of taxonomic and functional community composition. A new species (Cylindroiulus caeruleocinctus (Wood, 1864)) to the fauna of Budapest was found. Detritivore invertebrates depend on leaf litter and other dead organic matter types, therefore microsites providing these resources greatly improve their survival. Due to increasing urban disturbance, it is recommended to provide appropriate detritus and shelter sites as part of the management of green spaces in order to maintain species richness, abundance, and function of species.
\end{abstract}

Keywords: Central Europe; diversity; functional trait; species richness; species turnover

\section{Introduction}

Urban land-use is one of the most dominant forms of human activities in the world [1]. Urban areas continue to expand, causing anthropogenic disturbance of remaining natural habitats in a variety of ways; for example: Environmental pollution, habitat fragmentation, soil sealing and dispersion of exotic species, etc. Consequently, urban landscapes are generally characterized by destruction and a gradual replacement of native biota [2].

Urbanization, although causing local extinctions, does not always lead to a reduction in species richness, but rather to a shift in species composition, resulting in biotic homogenization of natural communities [3]. The idea that regardless of the "natural" and initial conditions, humans create similar landscapes in cities globally has been articulated in the "Urban Ecosystem Convergence Hypothesis" [4]. Homogenization of urban communities has been proven for several taxa, such as plants [5], microbes [6], insect orders [7,8] and birds [9]. However, soil macrodetrtivores, including millipedes, are heavily underrepresented in existing studies. 
The majority of urban studies have focused only on taxonomic $\alpha$ diversity (particularly on species richness) [3]. However, measuring $\beta$ diversity, based on between-site differences, is more effective in identifying factors shaping community structure. Mechanisms influencing community assembly act on biotic complementarities and redundancies among sites $[10,11]$. Biotic complementary means that species have niches with no overlap, while biotic redundancy refers to niche overlap. A low $\beta$ diversity is usually related to low heterogeneity in habitats, climatic conditions, or topography due to (anthropogenically driven) homogenization of these factors [12], thus making it highly relevant to understanding urban effects on biological communities. It is increasingly recognized that functional aspects of diversity are more directly linked to ecosystem functionality than taxonomic identity of species (e.g., [13]). Functional traits and their associated diversity indicate biotic interactions, niche complementarity, and environmental filtering [10]. It has been shown that better predictions of biological responses to habitat change may be gained from functional traits rather than taxonomic ones [14]. To understand the functionality of urban ecosystems better, an integrative approach is needed considering taxonomic and functional diversity at the same time. This is particularly important due to the significant role urban ecosystems play in providing ecosystem services with socio-economic benefits [15]. Although many ecosystem services are related to soils, soils and their biota have received little attention in urban context. Urban soils, like other soils, provide important ecosystem services, e.g., the maintenance of soil fertility and structural properties, filtering and providing a reservoir for water, nutrient cycling, and climate regulation [15]. Organic matter decomposition, as the most common ecosystem process in biogeochemical cycles, has an essential role in maintaining soil functions and quality [15].

Soil macrodetritivores significantly contribute to litter breakdown through their feeding and burrowing activities, thereby affecting organic matter level in soils [16]. Since millipedes (Diplopoda) are considered to be a key taxon in these ecological processes (particularly in temperate climates) [17], studying the diversity and composition of their assemblages is crucial. Millipedes are highly sensitive to disturbances and environmental changes, so they can be used as ecological indicators [18]. They are widespread, with limited dispersal abilities, and are relatively easy to collect and identify. It is well-known that microclimatic and edaphic factors represent strong environmental influences on the distribution of millipedes [19]. The most important soil characteristics for millipedes are soil texture, soil moisture content, temperature, mineral content (especially calcium and magnesium), and humus type $[19,20]$.

Due to the two biogeographically distinct parts of Budapest with differing biological and physicochemical conditions, this city offers an ideal situation for studying the effects of urbanization, including generality/specificity and biotic homogenization, on millipede assemblages.

Our aims were:

(1) To assess and compare millipede assemblages on the two sides of the city divided by the river Danube as a barrier;

(2) To investigate the taxonomic and functional diversity, and compositional response of millipedes to urban intensity;

(3) To identify the major soil properties shaping the structure of taxonomic and functional communities.

\section{Materials and Methods}

\subsection{Study Sites and Design}

The study was conducted in Budapest metropolitan area in Hungary. Budapest is the capital of Hungary and has about 1,752,000 inhabitants [21]. The city is divided by the Danube River, which separates the two major parts of the city, Buda and Pest. Buda (on the east bank of the river) can be characterized by a uniform parent rock, primarily limestone and dolomite, which forms a series of hills and valleys. The area included in this study is in the urbanized area of the Buda Hills, ranging 
from 300-500 $\mathrm{m}$ a.s.l. In contrast, Pest (on the west bank of the river) is mainly flat, generally 100-150 $\mathrm{m}$ a.s.l. and comprises the Danube floodplain, which overlies Triassic deposits. Their particular geological history led to very different landscapes with specific edaphic, botanical, and zoological characteristics [22]. Buda and Pest belong to the Matricum (Pilisicum sub-district) and Pannonicum (Eupannonicum sub-district) fauna districts, respectively [23].

For site selection, we aimed at covering a wide spectrum of typical urban woody habitats. We selected 23 sites in Buda and 24 sites in Pest (Figure 1) with differing levels of disturbance and degradation: Rural forests, urban forests, and other woody patches (e.g., city parks, gardens, cemeteries). Rural forests are semi-natural woodlands, situated in nature reserves surrounding the city.

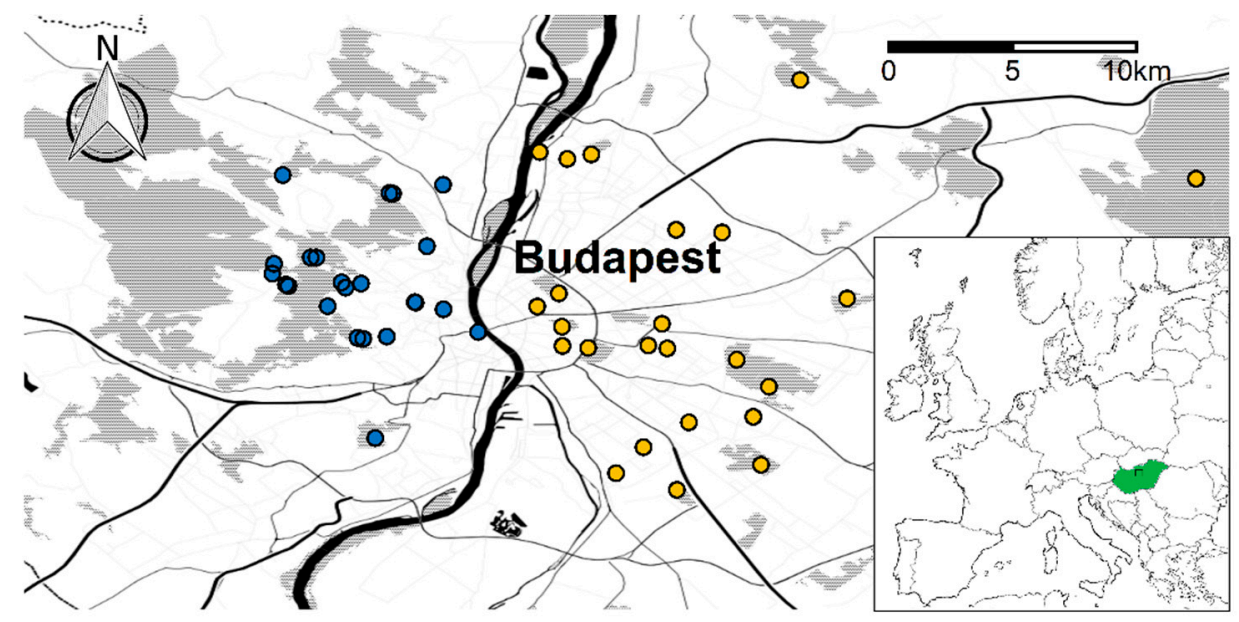

Figure 1. Locations of the sampling sites on the Buda $(N=23$, blue dots) and Pest sides $(N=24$, yellow dots) of Budapest. Inset: Map of Europe showing the position of Hungary and Budapest.

\subsection{Diplopoda}

\subsubsection{Sampling and Species Identification}

Millipedes were collected by time-restricted hand sorting (60 min per site) [24] during their main activity seasons (spring and autumn) in 2016 (Buda side) and in 2018 (Pest side). During sampling, special attention was paid to discover favorable microhabitats, such as leaf litter, fallen tree trunks or branches, and shelter sites under barks and stones in order to maximize species richness. Individuals were preserved in $70 \%$ ethanol. The specimens were identified to species level using the keys of Schubart [25] and Korsós [26].

\subsubsection{Taxonomic and Functional Diversity}

We assessed taxonomic and functional diversity of millipede assemblages for each individual site. Taxonomic $\alpha$ diversity was measured by species richness. To describe $\beta$ diversity, pairwise comparisons between all sites were computed using the Jaccard dissimilarity index. This index enables partitioning of $\beta$ diversity into the dissimilarity components due to species turnover (species replacement between communities) and nestedness (species loss or gain between communities) [27]. This method provides a more comprehensive picture of biotic homogenization, as the two components refer to different processes of community assembly [28]. The "beta.pair" function of the "betapart" $\mathrm{R}$ package was applied for calculation of the above-mentioned dissimilarity values [29].

Morphology (length and width) and ecological preference (habitat affinity, humidity preference, and disturbance sensitivity) of millipedes were used to characterize the functional structure and composition of assemblages (Table 1). Trait and preference values were based on a literature review (for values and literature sources, see Table S1, Supplementary Materials). Functional dispersion (FDis) index, as a representative of functional diversity, and community-weighted mean (CWM) trait score 
values were calculated using the "FD" R package [30]. FDis is the mean distance of species to the centroid of trait distribution. CWM represents the average of each trait/preference weighted by relative abundance/frequency [31].

Table 1. Selected traits and ecological preferences of Diplopoda species.

\begin{tabular}{cccc}
\hline & Trait & Type & Units/levels \\
\hline Morphological traits & length & quantitative & $\mathrm{mm}$ \\
& width & quantitative & mm \\
ECOLOGICAL PREFERENCES & habitat affinity & ordinal & 1 open habitat, 2 generalist, 3 forest specialist \\
& humidity preference & ordinal & 1 xerotolerant, 2 mesophilic, 3 hygrophilous \\
& disturbance sensitivity & ordinal & 1 insensitive, 2 moderately sensitive, 3 sensitive \\
\hline
\end{tabular}

\subsection{Environmental Factors}

\subsubsection{Landscape Structure Characteristics}

An urbanization index (UI) was applied to quantify urbanization intensity, as proposed by Liker et al. [32]. Vegetation cover, building density, and the presence of sealed surface (roads) were scored for 100 cells of a $400 \times 400 \mathrm{~m}$ area around each study site using the QGIS software (version: 2.16). For each site, urbanization index was calculated by extracting the first principal component (PCA1) from a principal component analysis (PCA) of five urbanization variables (mean building density, number of cells with high building density, number of cells with road, mean vegetation density, number of cells with high vegetation density).

\subsubsection{Soil Properties}

Composite samples consisting of 10 subsamples were taken randomly from the $0-15 \mathrm{~cm}$ topsoil layer of each study site. Soil $\mathrm{pH}\left(\mathrm{H}_{2} \mathrm{O}\right)$ was measured in 1:2.5 soil/water suspensions for $12 \mathrm{~h}$ after mixing. Soil organic matter (SOM) was determined by the standard ignition method [33]. The total soluble salt content of soils was measured with a conductometer (Radelkis OK-102/1). To characterize soil texture, saturation percentage (SP), referring to the mechanical constituents of soils (as a proxy of soil plasticity), was applied [34]. Soil $\mathrm{CaCO}_{3}$ was determined with a Labor MIM calcimeter [35].

\subsection{Statistical Analyses}

All statistical analyses were performed in $\mathrm{R}$ software version 3.2.5., using the $\mathrm{R}$ packages "lme4" [36], "mvabund" [37], "nparcomp" [38], and "vegan" [39].

Principal component analysis (PCA) was used to compare the two sides of Budapest based on topsoil characteristics of study sites. To determine the response of soil characteristics to urbanization, general linear mixed models (LMMs) were applied. Relationships between species/functional richness and environmental variables (edaphic factors and urbanization index) were analyzed by LMMs. After fitting the full models for each dependent variable, we used the Akaike Information Criterion (AIC) to select the most parsimonious model. To determine whether soil properties and urbanization had significant effects on taxonomic and functional assemblage composition, permutational multivariate variance of analyses (PERMANOVAs, Jaccard and Bray-Curtis dissimilarity index, respectively; permutation $=9999$ ) were applied. Results were visually displayed using non-metric multidimensional scaling (NMDS). Multivariate generalized linear models for presence-absence data ("manyglm" function, family = binomial) were used to evaluate individual species responses. For functional group responses, LMMs on CWM values for each attribute of a given trait/preference were carried out. These models complement PERMANOVAs by providing univariate responses to factors, in addition to overall multivariate responses. To consider and test the effects of the study sites' size variability, the "area" variable was included in the models. The "side" variable (Buda, Pest) was considered as a random factor. To assess how taxonomic $\beta$ diversity (turnover and nestedness) changed with urban intensity, the study sites of Buda and Pest were divided into three categories (UI1: Least urbanized; UI2: 
Moderately urbanized; UI3: Highly urbanized) based on urbanization index. For multiple comparisons of dissimilarity values among the three habitat types, nonparametric two-sided Tukey-type tests were applied using the "nparcomp" function.

\section{Results}

\subsection{Taxonomic Diversity and Species Composition of Diplopoda Assemblages}

A total of 24 species belonging to 8 families were identified in the 47 study sites of Budapest (Table 2). Total species richness was 14 and 20 on Buda and Pest sides, respectively. The average species number of millipedes (mean \pm standard deviation (SD)) was $3.7 \pm 1.5$ per site in Buda compared to $4.1 \pm 2.4$ per site in Pest, with no significant difference between the two sides of the city. The most species-rich sampling sites contained 6 and 11 species in Buda and Pest, respectively (Tables S2-S3, Supplementary Materials). We found a new species to the fauna of the city, Cylindroiulus caeruleocinctus (Wood, 1864), which occurred only in one city park on the Pest side. The most frequent species were Cylindroiulus boleti (68.1\%) and Ophyiulus pilosus (59.6\%). The number of species was negatively influenced by the urbanization index $(t=-3.5, p=0.001$; Figure 2A).

Table 2. Species list of millipedes with their frequency of occurrence in Buda and Pest. Abbreviations of species names used in Figure 4A.

\begin{tabular}{|c|c|c|c|c|}
\hline \multirow{2}{*}{ Family } & \multirow{2}{*}{ Species } & \multirow{2}{*}{ Abbreviations } & \multicolumn{2}{|c|}{ Frequency (\%) } \\
\hline & & & Buda & Pest \\
\hline \multirow[t]{2}{*}{ Blaniulidae } & Blaniulidae sp. & Blsp & 4.3 & 12.5 \\
\hline & Proteroiulus fuscus (Am Stein, 1857) & Prfu & 0 & 4.2 \\
\hline Chordeumatidae & Chordeuma sylvestre C. L. Koch, 1847 & Chsy & 4.3 & 0 \\
\hline Dorypetalidae & Dorypetalum degenerans (Latzel, 1884) & Dode & 13 & 0 \\
\hline Glomeridae & Glomeris hexasticha Brandt, 1833 & Glhe & 13.0 & 8.3 \\
\hline \multirow[t]{12}{*}{ Julidae } & Brachyiulus bagnalli Brölemann, 1924 & Brba & 0 & 29.2 \\
\hline & Cylindroiulus boleti (C. L. Koch, 1847) & Cybo & 78.3 & 58.3 \\
\hline & Cylindroiulus caeruleocinctus (Wood, 1864) & Cyca & 0 & 4.2 \\
\hline & Cylindroiulus sp. & Cysp & 0 & 8.3 \\
\hline & Julus scandinavius (Latzel, 1884) & Jusc & 8.7 & 0 \\
\hline & Kryphioiulus occultus (Koch, C. L., 1847) & Kroc & 0 & 33.3 \\
\hline & Leptoiulus trilineatus (Koch, C. L., 1847) & Letrili & 43.5 & 0 \\
\hline & Leptoiulus trilobatus Verhoeff, 1894 & Letrilo & 0 & 4.2 \\
\hline & Megaphyllum projectum Verhoeff, 1894 & Mepr & 8.7 & 20.8 \\
\hline & Megaphyllum unilineatum (Koch, 1838) & Meun & 4.3 & 58.3 \\
\hline & Ommatoiulus sabulosus (Linnaeus, 1758) & Omsa & 39.1 & 25.0 \\
\hline & Ophyiulus pilosus (Newport, 1843) & Oppi & 82.6 & 37.5 \\
\hline \multirow[t]{2}{*}{ Mastigophorophyllidae } & Mastigona bosniensis(Verhoeff, 1897) & Mabo & 21.7 & 25.0 \\
\hline & Mastigona sp. & Masp & 0 & 4.2 \\
\hline \multirow[t]{4}{*}{ Polydesmidae } & Brachydesmus sp. & Brsp & 17.4 & 20.8 \\
\hline & Eubrachydesmus superus (Latzel, 1884) & Eusu & 0 & 12.5 \\
\hline & Polydesmus complanatus (Linnaeus, 1761) & Poco & 0 & 20.8 \\
\hline & Polydesmus sp. & Posp & 0 & 16.7 \\
\hline Polyxenidae & Polyxenus lagurus (Linnaeus, 1758) & Pola & 30.4 & 4.2 \\
\hline
\end{tabular}



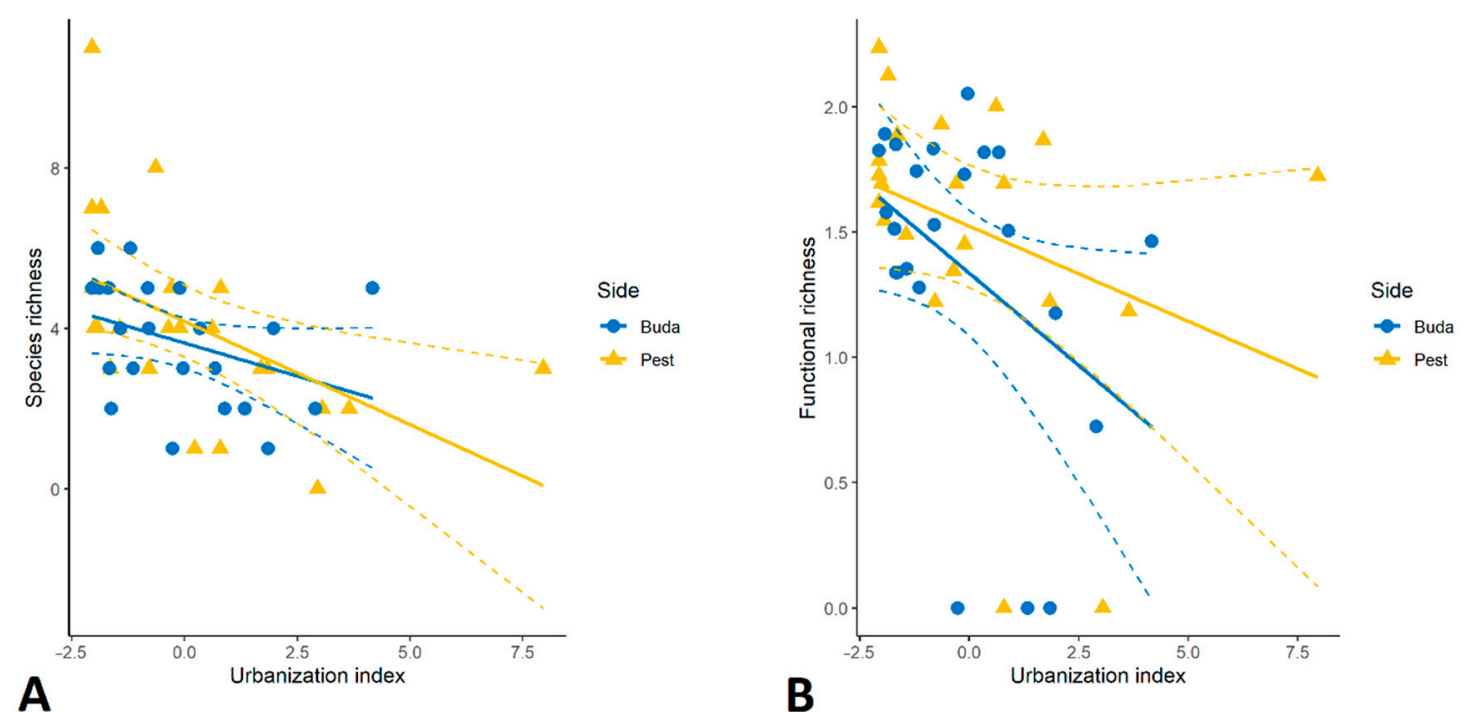

Figure 2. Relationship between species richness (A), functional richness (B) and urbanization on the two sides of Budapest. Dashed lines represent $95 \%$ confidence intervals.

There were significant differences among urban habitat categories in dissimilarity values, with no consistent tendency in Buda or Pest. The level of taxonomic dissimilarity (taxonomic $\beta$ diversity) was significantly higher among the most urbanized sites (UI3) than the least (UI1) and moderately urbanized (UI2) ones in Buda ( $p=0.005$ and $p=0.002$, respectively). The contribution of species turnover to taxonomic dissimilarity among sites was highest in the UI3 category, differing significantly from UI2 $(p=0.044)$. The dissimilarity values in Pest showed a slightly different pattern. The moderately urbanized habitats (UI2) were characterized by the highest taxonomic $\beta$ diversity and species turnover, and significantly differed from U1 ones ( $p=0.013$ and $p=0.025$, respectively; Figure 3).
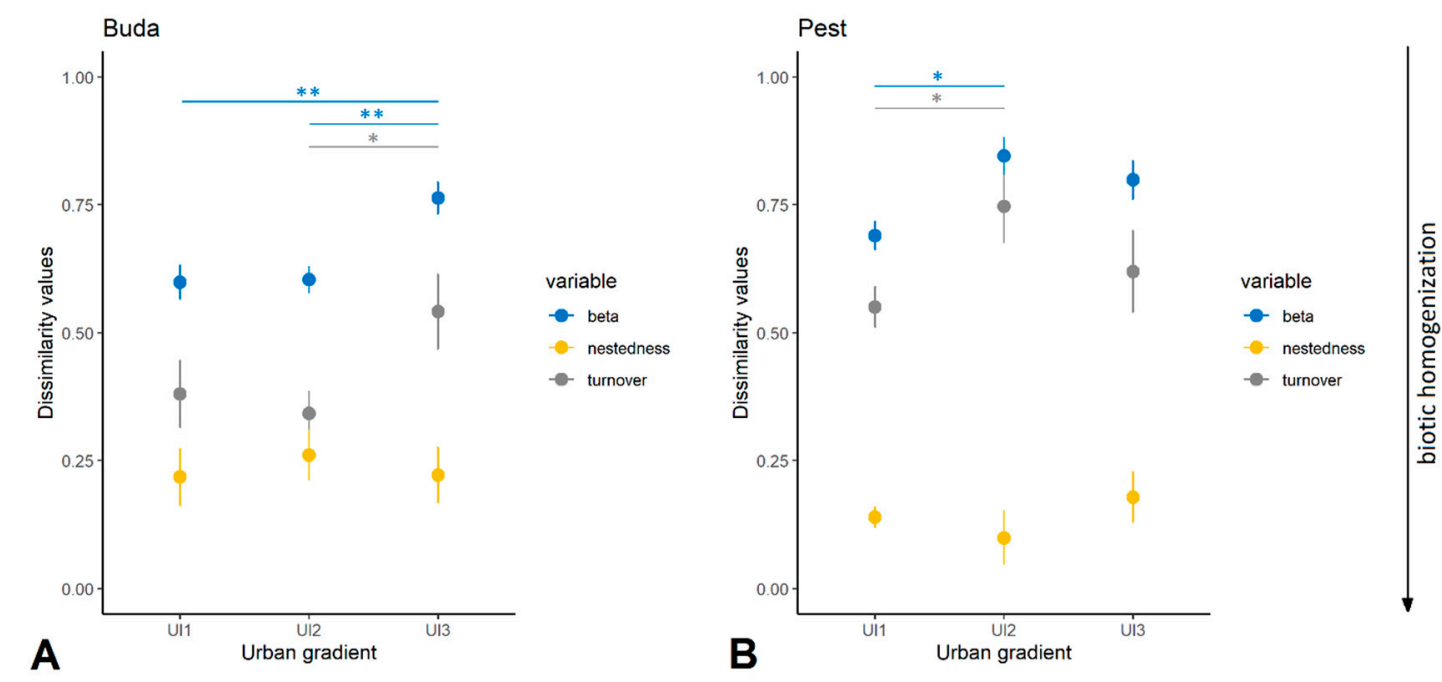

Figure 3. Multiple comparisons of dissimilarity values ( $\beta$ diversity, nestedness, and turnover) along an urban gradient in Buda (A) and Pest (B). Abbreviations: UI1, least urbanized; UI2, moderately urbanized; UI3, highly urbanized. Statistical significance is determined at ${ }^{* *} p<0.01$ and ${ }^{*} p<0.05$.

Significant differences in species composition of Diplopoda assemblages were experienced between the two sides of Budapest $\left(R^{2}=0.14, p<0.001\right.$; Figure $\left.4 \mathrm{~A}\right)$. There was higher variability in taxonomic composition in Pest than the Buda side. NMDS analysis resulted in two clearly separated groups of sites. Many species occurred either only in Buda or in Pest (Table 2). Ophyiulus pilosus (Dev $=10.4$, $p=0.021)$, Megaphyllum unilineatum (Dev = 18.0, $p=0.001)$, Kryphyoiulus occultus (Dev $=12.3, p=0.008)$, 
and Brachyiulus bagnalli (Dev $=10.6, p=0.021$ ) were more common in Pest, while Leptoiulus trilineatus $(D e v=17.2, p=0.001)$ was exclusively found in Buda. The degree of urbanization had significant effects on species composition $\left(R^{2}=0.08, p<0.001\right.$; Figure $\left.4 \mathrm{~A}\right)$. For individual species responses, Cylindroiulus boleti $($ Dev $=29.53, p=0.001)$, Megaphyllum projectum $($ Dev $=11.0, p=0.039)$, and Mastigona bosniensis $(\operatorname{Dev}=14.5, p=0.006)$ showed negative relationship with urban disturbance.
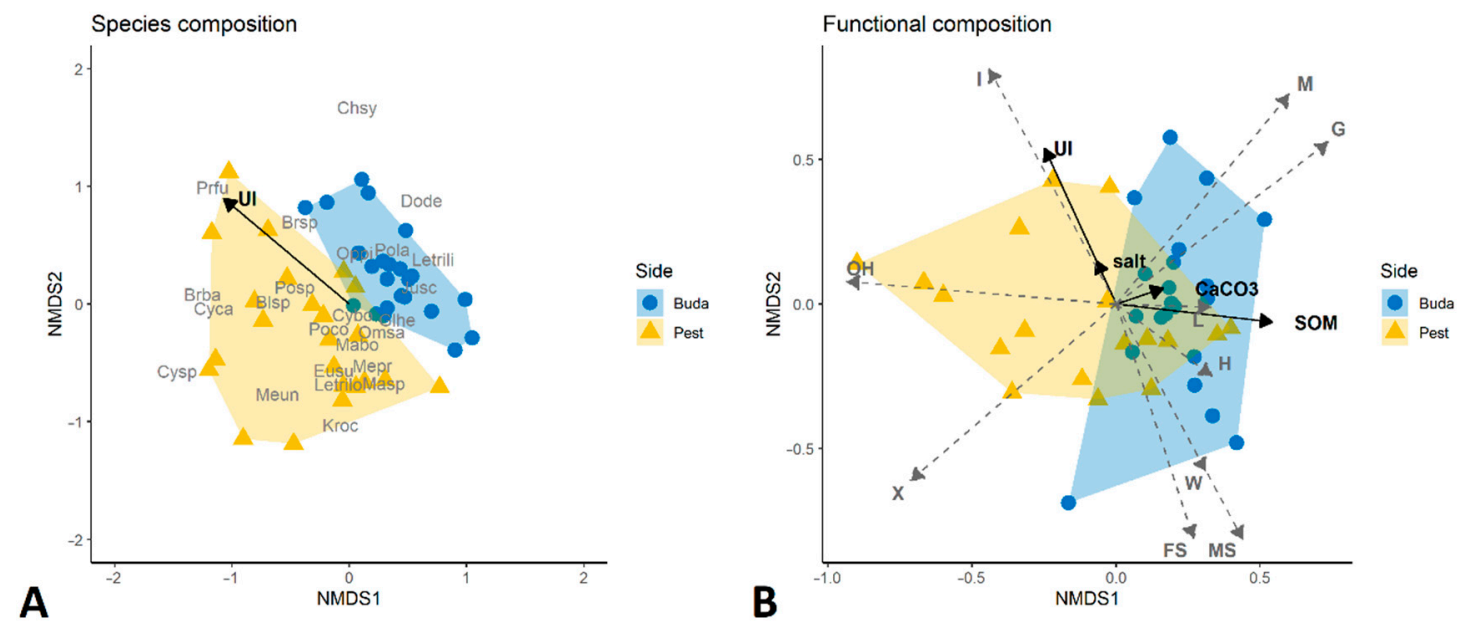

Figure 4. Non-metric multidimensional scaling (NMDS) analyses of taxonomic (A) and functional (B) composition of Diplopoda assemblages. For abbreviations of species names, see Table 2. The significant environmental variables are indicated by black arrows: UI, urbanization index; SOM, soil organic matter. The grey dashed arrows indicate the functional traits/ecological preferences: L, length; W, width; FS, forest specialist; G, generalist; H, hygrophilous; I, insensitive; M, mesophilic; MS, moderately sensitive; $\mathrm{OH}$, open habitat; $X$, xerotolerant.

\subsection{Traits Analysis and Functional Diversity}

The list of functional traits/ecological preferences for the different species is presented in Table S1. Both species richness and functional richness (expressed as FDis) decreased with the urbanization index $(t=-2.4, p=0.02$; Figure 2B). Diplopoda assemblages were functionally different across the sides of Budapest $\left(R^{2}=0.19, p<0.001\right.$; Figure $\left.4 \mathrm{~B}\right)$. Xerotolerant species and species preferring open habitats occurred mainly in sites in Pest $(t=2.6, p=0.01$ and $t=2.2, p=0.03$, respectively), while species with higher humidity preference ("mesophilic" category in this study) were more frequent on the Buda side $(t=3.4, p<0.001)$. Urbanization had significant effects on the functional composition of millipedes $\left(R^{2}=0.19, p<0.001\right.$; Figure 4B).

Regarding morphological traits, species bigger in size (longer and wider) prevailed in less urbanized habitats (length: $t=-2.9, p=0.005$; width: $t=-5.2, p<0.001$ ). Insensitive- and open habitat-preferring species were dominant in more urbanized sites $(t=4.4, p<0.001$ and $t=2.6, p=0.01$, respectively). Forest specialists and species moderately sensitive to urban intensity were less frequent or absent in disturbed habitats $(t=-2.7, p=0.01$ and $t=-4.4, p<0.001$, respectively).

\subsection{Diplopoda Assemblages and Soil Properties}

Topsoil characteristics of habitats showed a significant difference between the two sides of Budapest (Tables S4 and S5, Supplementary Materials). The PCA biplot resulted in two distinct, non-overlapping groups of study sites (Figure 5). The first two principal components explained $71.4 \%$ of the total variance of the dataset. Sites located in Buda were characterized by soils with higher $\mathrm{pH}$, saturation percentage (SP), and $\mathrm{CaCO}_{3}$ and $\mathrm{SOM}$ content. Soil $\mathrm{pH}$ and SP were significantly affected by urbanization. Soils of more urbanized habitats had higher $\mathrm{pH}(t=2.0, p=0.050)$ and lower soil plasticity $(t=-2.7, p=0.007)$ compared to less disturbed sites. 


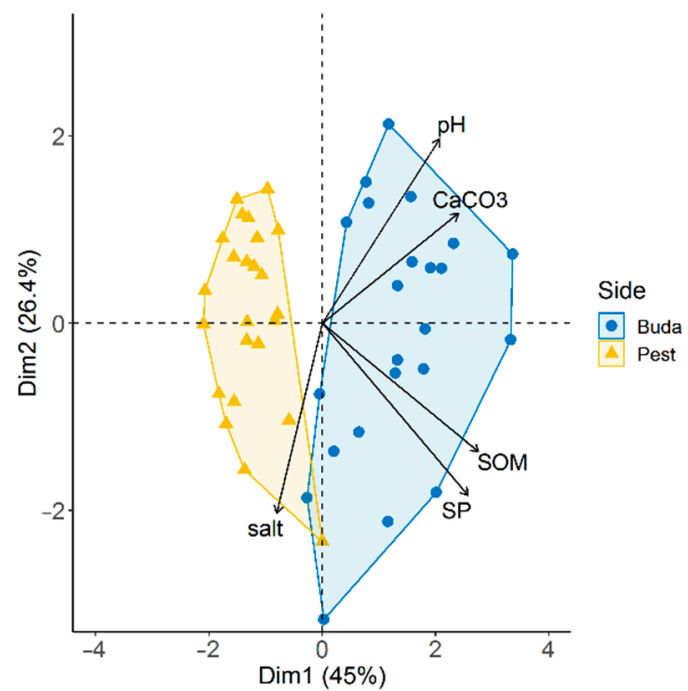

Figure 5. Principal component analysis (PCA) biplot of the sample sites according to the studied edaphic factors. Abbreviations: SOM, soil organic matter; SP, saturation percentage.

We found no significant effects of the studied edaphic factors on species composition of millipedes. However, the functional composition of Diplopoda assemblages was significantly influenced by $\mathrm{CaCO}_{3}$, SOM, and salt content of soils (Figure 4B, Table 3). Community weighted mean (CWM) values for several ecological preferences were influenced by the studied soil properties (Table 3). SOM content had positive effects on xerotolerant and moderately sensitive species, and negative effects on insensitive and mesophilic species. $\mathrm{CaCO}_{3}$ content of soils positively affected forest specialists. We found a positive correlation between the occurrence of mesophilic species and the total soluble salt content of soils.

Table 3. Results of the general linear mixed models showing significant relationships between functional trait levels and edaphic factors. SOM: soil organic matter.

\begin{tabular}{ccccc}
\hline Traits/Ecological Preferences & Levels & Edaphic Factors & $\boldsymbol{t}$ & $\boldsymbol{p}$ \\
\hline Habitat AFFINITY & forest specialist & $\mathrm{CaCO}_{3}$ & 2.7 & 0.01 \\
Humidity PREFERENCE & xerotolerant & $\mathrm{SOM}$ & 2.0 & 0.05 \\
& mesophilic & $\mathrm{SOM}$ & -2.7 & 0.01 \\
& & $\mathrm{salt}$ & 2.6 & 0.02 \\
DistURbanCE SENSITIVITY & insensitive & $\mathrm{SOM}$ & -3.8 & $<0.001$ \\
& moderately sensitive & $\mathrm{SOM}$ & 3.8 & $<0.001$ \\
\hline
\end{tabular}

\section{Discussion}

\subsection{Diplopoda Fauna of Budapest}

The 24 millipede species found in our survey represent $23 \%$ of the Hungarian millipede fauna [40]. Most of the recorded species are widespread in Europe [41,42]. Millipedes from urban and other anthropogenic habitats were previously investigated in several European cities [43-53]. Discussing some of these data, Vilisics et al. [53] stated that urban areas can be characterized by 14-26 species on average.

Korsós [47] and later Korsós et al. [48] provided data on the Diplopoda fauna of Budapest, including different types of man-made habitats, e.g., glasshouses, city gardens, secondary disturbed woods, cemeteries, large park forests, and floodplain forests of the Danube. These studies found 27 and 26 species, respectively, which was similar to our results. However, typical glasshouse millipedes (e.g., Choneiulus palmatus, Oxidus gracilis, Cylindroiulus truncorum) were missing from our species list due to our study focusing only on a subset of the diverse urban habitat types. The most frequent 
species, Cylindroiulus boleti and Ophyiulus pilosus, are sylvicol, although O. pilosus has been found in a wide variety of habitats such as gardens, parks, and meadows [42]. Our survey is the first record of Cylindroiulus caeruleocinctus in Budapest. This is a strongly synanthropic species, predominantly occurring in gardens, parks, cemeteries, orchards, waste places, and cultivated ground [28].

The present study is the first to compare the millipedes of the two sides of Budapest, both faunistically and ecologically. Our results show that Buda and Pest have significantly different Diplopoda fauna. Xerotolerant species typical of open land (B. bagnalli, K. occultus, M. unilineatum) were constant elements of habitats in Pest, mainly characterized by flat landscapes. By contrast, a mesophilic species, L. trilineatus [54]. was exclusively found on the Buda side, which may be explained by a more humid macroclimate associated with the region of the Buda Hills [22]. The large difference in community composition is due to both sides of the city having respective regional species pools.

\subsection{Urban Effects on Taxonomic/Functional Diversity and Composition of Millipedes}

Taxonomic diversity of Diplopoda has been previously investigated in urban contexts, but to our knowledge, this is the first study that explicitly explores the urban effects on functional richness. We found that urbanization has a negative effect on species and functional richness of millipede assemblages on both sides of Budapest. Mwabvu [55], studying spirostreptid millipedes, also reported that species richness decreased with increasing urban disturbance. In a rural-urban gradient study (Debrecen, Hungary), Bogyó et al. [43] found the highest millipede abundance, species richness, and diversity in the suburban area. Higher functional diversity of millipedes was observed in less urbanized habitats that are rich in decaying wood and leaf litter, as reported by Nagy et al. [56] for woodlice. Similarly, Fournier et al. [57] found a negative functional response of millipedes to disturbance in a restored floodplain. Urban green area management (e.g., litter removal), together with the limited dispersal ability of millipedes [19], hindered recolonization [58,59].

Our aim was to also test whether-and if so, how-urbanization has altered processes of community assembly, leading to biotic homogenization. The homogenization of millipede assemblages has been inferred from the reductions in between-site dissimilarity in terms of species composition ( $\beta$ diversity) along an urban gradient. Contrary to our expectations, $\beta$ diversity (and species turnover) seemed to increase with increasing urban intensity. Homogenization of urban communities has been previously observed in several taxa (e.g., plants [5], microbes [6], insect orders [7,8], and birds [9]). However, the relationship between urbanization and similarity is complex. For example, Jokimäki and Kaisanlahti-Jokimäki [60] found lower avifaunal similarity among more urbanized (town centers) compared to less urbanized habitats (apartment blocks and single-family houses) in five European towns. Similarly to our results, Magura et al. [61] did not experience the homogenization effect of urbanization on ground beetles. On the one hand, spatial (e.g., dispersal limitation), environmental (e.g., habitat filtering) and/or biological (e.g., limiting similarity) factors may contribute to such enhancement of $\beta$ diversity [62]. On the other hand, biotic homogenization is a time-dependent process and it may take longer for the rearrangement of communities [63]. An additional explanation for our results could be that certain species ("matrix species") can easily colonize microhabitats of altered forest fragments in urban areas, and such unpredictable colonization success may lead to heterogeneous and differing assemblages [61].

Regarding individual species responses, three forest species that are very common in Central European woodlands [41,42], proved to be sensitive to urbanization: C. boleti, M. projectum, and M. bosniensis. These species preferred suburban and rural areas in the urban study of Bogyó et al. [43]. Habitat loss and fragmentation resulted from urban sprawling lead to a drastic decline of forest specialists [64], as we have shown in the present study. Our traits-based analysis also confirmed that forest species are more sensitive to disturbance. By contrast, certain millipedes-mainly belonging to open land and generalist species—showed different habitat preferences, and their occurrence increased with urban intensity. These synanthropic species have adapted to disturbed and often man-made habitats [65]. Our results are consistent with previous studies on other soil arthropod taxa (e.g., 
spiders [66], beetles [61], woodlice [67,68], and millipedes [43]) in that the ratio of forest specialist to synanthropic species decreases with urbanization. Moreover, we observed a negative correlation between higher urban disturbance and smaller body size (length and width based on literature data) of millipedes. Similar results were published by Bogyó et al. [43] and Magura et al. [69], who found significantly smaller individuals of millipedes and ground beetles in urban areas compared to rural and suburban ones, respectively. This phenomenon may be related to the deterioration of soil habitat quality. Urban soils are exposed to a variety of direct (e.g., sealing, trampling, chemical contamination) and indirect (e.g., urban heat island effect, anthropogenic disturbance) adverse effects [15]. In our study, soil $\mathrm{pH}$ and texture were significantly influenced by urban intensity. Several previous studies have shown that urban soils, especially those disturbed and/or heavily managed, typically have higher $\mathrm{pH}$, which has been associated with materials used in urban infrastructure that are high in calcium, such as concrete [70,71]. Anthropogenic activities often result in soil degradation, as shown by the lower saturation percentage values in more disturbed habitats, indicating lost or strongly modified soil structure [70,72]. These habitat modifications could significantly reduce the survival and fitness of millipedes [19]. The smaller body size in more urbanized sites may be a result of lower food quality [73], higher concentration of contaminants (e.g., heavy metals released by fuel combustion emissions), and/or lower soil moisture [19]. Physical soil disturbance, sparse vegetation (and litter layer), and higher urban temperatures are known to favor rapid water loss/desiccation of the topsoil. The humidity level is an important filter for Diplopoda [64], especially in disturbed soil habitats. Their exoskeleton is permeable to water; therefore, risk of desiccation restricts their occurrence to habitats with higher humidity and suitable shelter sites, such as woody debris and leaf litter [19]. Urban environmental changes can act as a filter, removing all the species lacking specific combinations of traits, as described by Keddy [74].

\subsection{Diplopoda Assemblages and Soil Properties}

Relatively large differences in edaphic factors were observed between the two sides of the city, which can partly explain the compositional dissimilarities. The functional composition of assemblages was significantly influenced by $\mathrm{CaCO}_{3}, \mathrm{SOM}$, and total soluble salt content of soils. As millipedes require calcium sources to develop their calcified exoskeleton [19], calcium availability affects their presence. In this study, forest specialists showed positive response to soil $\mathrm{CaCO}_{3}$ content. For example, typical forest species, Glomeris hexasticha and Chordeuma sylvestre, have been shown to be calciphilic $[25,75]$. Some ecological preferences (humidity and disturbance tolerance) were significantly correlated to SOM content. In general, millipedes, as detritus feeders, are indirectly influenced by SOM content, rather than directly [16]. The presence and type of humus are known to have crucial importance for millipedes [76]. Organic matter levels affect fertility, structure, buffer, and water-holding capacity of soils, thus have an essential role in defining soil habitat quality [16]. The concentration of total soluble salt in soils also proved to be an important edaphic factor in functional community assembly. This may be related to the osmotic effect of salts, which significantly determine the water balance of soil-dwelling organisms [77].

\section{Conclusions}

Our study showed that urban soil disturbance has detrimental effects on species and functional richness of Diplopoda assemblages on both sides of Budapest. Urbanization was the most important driver of taxonomic and functional community assembly. Species had different responses to anthropogenic habitat modification, depending on their ecological needs and tolerance. Although urbanization seemingly did not homogenize Diplopoda assemblages in Budapest, its generality should be tested in more locations or cities. The decline in taxonomic and functional diversity of millipedes could result in strong alteration in soil organic matter dynamics due to the vital functional importance of millipedes in urban ecosystems across the ranges of nutrient cycling and organic matter decomposition [16]. Urban green spaces are usually heavily managed and litter is removed, which 
results in increasing urban disturbance for litter-dwelling invertebrates. It would benefit them to provide appropriate supplies of detritus and shelter sites, as this would promote species richness, abundance, and function. We therefore recommend management of natural habitat remnants within cities be "invertebrate friendly".

Supplementary Materials: The following is available online at http://www.mdpi.com/2075-4450/11/1/25/s1: Table S1, Trait values for each species, used in the analysis of the traits/ecological preferences. Table S2, Species occurrence of study sites on the Buda side of the Budapest metropolitan area. $\times$ indicates presence. Table S3, Species occurrence of study sites on the Pest side of the Budapest metropolitan area. $\times$ indicates presence. Table S4, Geographical location and habitat characterization (urbanization intensity and topsoil characteristics) of study sites on the Buda side of the Budapest metropolitan. Table S5, Geographical location and habitat characterization (urbanization intensity and topsoil characteristics) of study sites on the Pest side of the Budapest metropolitan.

Author Contributions: Conceptualization, Z.T. and E.H.; methodology, Z.T. and E.H.; software, Z.T.; validation, Z.T. and E.H.; formal analysis, Z.T.; investigation, Z.T. and E.H.; resources, E.H.; data curation, Z.T.; writing-original draft preparation, Z.T.; writing-review and editing, Z.T. and E.H.; visualization, Z.T.; supervision, E.H.; project administration, Z.T.; funding acquisition, E.H. All authors have read and agreed to the published version of the manuscript.

Funding: This research was funded by the European Union and co-financed by the European Social Fund (grant agreement no. EFOP-3.6.2- 16-2017-00012, project title: Development of a product chain model for functional, healthy and safe foods from farm to fork based on a thematic research network).

Acknowledgments: The authors are grateful to A. Kásler and H. Novoszáth (University of Veterinary Medicine Budapest, Hungary) for their help in the fieldwork. They acknowledge the four anonymous reviewers and the editors for their detailed comments, which substantially improved the manuscript. The authors would also like to thank Eszter Wainwright-Déri (Zoological Society of London) and Mark Hassall (University of East Anglia) for their important contribution to the linguistic improvement of the text.

Conflicts of Interest: The authors declare no conflicts of interest.

\section{References}

1. United Nations. Department of Economic and Social Affairs, Population Division. World Urbanization Prospects: The 2018 Revision (ST/ESA/SER.A/420); United Nations: New York, NY, USA, 2019.

2. McKinney, M.L. Urbanization, biodiversity, and conservation. Bioscience 2002, 52, 883-890. [CrossRef]

3. McKinney, M.L. Effects of urbanization on species richness: A review of plants and animals. Urban Ecosyst. 2008, 11, 161-176. [CrossRef]

4. Pouyat, R.V.; Russell-Anelli, J.; Yesilonis, I.D.; Groffman, P.M. Soil carbon in urban forest ecosystems. In The Potential of U.S. Forest Soils to Sequester Carbon and Mitigate the Greenhouse Effect; Kimble, J.M., Heath, L.S., Birdsey, R.A., Lal, R., Eds.; CRC Press: Boca Raton, FL, USA, 2003; pp. 347-362.

5. Schwartz, M.W.; Thorne, J.H.; Viers, J.H. Biotic homogenization of the California flora in urban and urbanizing regions. Biol. Conserv. 2006, 127, 282-291. [CrossRef]

6. Epp Schmidt, D.J.; Pouyat, R.; Szlavecz, K.; Setälä, H.; Kotze, D.J.; Yesilonis, I.; Cilliers, S.; Hornung, E.; Dombos, M.; Yarwood, S.A. Urbanization erodes ectomycorrhizal fungal diversity and may cause microbial communities to converge. Nat. Ecol. Evol. 2017, 1, 0123. [CrossRef]

7. Knop, E. Biotic homogenization of three insect groups due to urbanization. Glob. Chang. Biol. 2016, 22, 228-236. [CrossRef]

8. Lizée, M.H.; Mauffrey, J.F.; Tatoni, T.; Deschamps-Cottin, M. Monitoring urban environments on the basis of biological traits. Ecol. Indic. 2011, 11, 353-361. [CrossRef]

9. van Rensburg, B.J.; Peacock, D.S.; Robertson, M.P. Biotic homogenization and alien bird species along an urban gradient in South Africa. Landsc. Urban Plan. 2009, 92, 233-241. [CrossRef]

10. McGill, B.J.; Enquist, B.J.; Weiher, E.; Westoby, M. Rebuilding community ecology from functional traits. Trends Ecol. Evol. 2006, 21, 178-185. [CrossRef]

11. Flynn, D.F.B.; Mirotchnick, N.; Jain, M.; Palmer, M.I.; Naeem, S. Functional and phylogenetic diversity as predictors of biodiversity-ecosystem-function relationships. Ecology 2011, 92, 1573-1581. [CrossRef]

12. McGill, B.J.; Dornelas, M.; Gotelli, N.J.; Magurran, A.E. Fifteen forms of biodiversity trend in the Anthropocene. Trends Ecol. Evol. 2015, 30, 104-113. [CrossRef]

13. Cadotte, M.W.; Carscadden, K.; Mirotchnick, N. Beyond species: Functional diversity and the maintenance of ecological processes and services. J. Appl. Ecol. 2011, 48, 1079-1087. [CrossRef] 
14. Hedde, M.; van Oort, F.; Lamy, I. Functional traits of soil invertebrates as indicators for exposure to soil disturbance. Environ. Pollut. 2012, 164, 59-65. [CrossRef] [PubMed]

15. Pavao-Zuckerman, M.A. Urbanization, soils and ecosystem services. In Soil Ecology and Ecosystem Services; Wall, D.H., Bardgett, R.D., Behan-Pelletier, V., Herrick, J.E., Jones, T.H., Ritz, K., Six, J., Strong, D.R., van der Putten, W.H., Eds.; Oxford University Press: Oxford, UK, 2012; pp. 270-281.

16. Lavelle, P.; Spain, A.V. Soil Ecology; Kluwer Academic Publishers: Dordrecht, The Netherlands, 2001.

17. Edwards, C.A. Macroarthropods. In Biology of Plant Litter Decomposition; Dickinson, C.H., Pugh, G.J.F., Eds.; Academic Press: London, UK, 1974; Volume 2, pp. 533-555.

18. Paoletti, M.G.; Osler, G.H.R.; Kinnear, A.; Black, D.G.; Thomson, L.J.; Tsitsilas, A.; Sharley, D.; Judd, S.; Neville, P.; D'Inca, A. Detritivores as indicators of landscape stress and soil degradation. Aust. J. Exp. Agric. 2007, 47, 412-423. [CrossRef]

19. Hopkin, S.P.; Read, H.J. The Biology of Millipedes; Oxford University Press: Oxford, UK, 1992.

20. Kime, R.D.; Wauthy, G. Aspects of relationships between millipedes, soil texture and temperature in deciduousnforests. Pedobiologia 1984, 26, 387-402.

21. Hungarian Central Statistical Office. Available online: https://www.ksh.hu/docs/hun/xstadat/xstadat_eves/i_ wdsd003c.html (accessed on 15 October 2019).

22. Tóth-Ronkay, M.; Bajor, Z.; Bárány, A.; Földvári, G.; Görföl, T.; Halpern, B.; Leél-Őssy, S.; Mészáros, R.; Péntek, A.L.; Tóth, B.; et al. Vertebrates and Invertebrates of European Cities: Selected Non-Avian Fauna; Kelcey, J.G., Ed.; Springer: Berlin, Germany, 2016; pp. 27-73.

23. Varga, Z. Animals. In National Atlas of Hungary: Natural Environment; Kocsis, K., Ed.; MTA CSFK Geographical Institute: Budapest, Hungary, 2018; pp. 104-111.

24. Snyder, B.A.; Draney, M.L.; Sierwald, P. Development of an optimal sampling protocol for millipedes (Diplopoda). J. Insect Conserv. 2006, 10, 277-288. [CrossRef]

25. Schubart, O. Tausendfüssler oder Myriapoda I: Diplopoda. In Die Tierwelt Deutschlands und der angränzenden Meeresteile, Teil 28; Dahl, F., Ed.; Gustav Fischer Verlag: Jena, Germany, 1934; p. 318.

26. Korsós, Z. Magyarország Ikerszelvényesei. Illusztrációtáblák és Adatlapok a Fajok Meghatározásához (Diplopods of Hungary. Illustrations and Data Sheets to Species Identification); Hungarian Natural History Museum: Budapest, Hungary, 2015.

27. Baselga, A. The relationship between species replacement, dissimilarity derived from nestedness, and nestedness. Glob. Ecol. Biogeogr. 2012, 21, 1223-1232. [CrossRef]

28. Baselga, A. Partitioning the turnover and nestedness components of beta diversity. Glob. Ecol. Biogeogr. 2010, 19, 134-143. [CrossRef]

29. Baselga, A.; Orme, C.D.L. betapart: An R package for the study of beta diversity. Methods Ecol. Evol. 2012, 3, 808-812. [CrossRef]

30. Laliberte, E.; Legendre, P. A distance-based framework for measuring functional diversity from multiple traits. Ecology 2010, 91, 299-305. [CrossRef]

31. Garnier, E.; Cortez, J.; Billès, G.; Navas, M.-L.; Roumet, C.; Debussche, M.; Laurent, G.; Blanchard, A.; Aubry, D.; Bellmann, A.; et al. Plant functional markers capture ecosystem properties during secondary succession. Ecology 2004, 85, 2630-2637. [CrossRef]

32. Liker, A.; Papp, Z.; Bókony, V.; Lendvai, Á.Z. Lean birds in the city: Body size and condition of house sparrows along the urbanization gradient. J. Anim. Ecol. 2008, 77, 789-795. [CrossRef] [PubMed]

33. ASTM D2974-14. Standard Test Methods for Moisture, Ash, and Organic Matter of Peat and Other Organic Soils; ASTM International: West Conshohocken, PA, USA, 2014.

34. Westerman, R.L. Soil Testing and Plant Analysis; Soil Science Society of America: Madison, WI, USA, 1990.

35. ISO 10693. Soil Quality—Determination of Carbonate Content_Volumetric Method; International Organization for Standardization: Geneva, Switzerland, 1995.

36. Bates, D.; Maechler, M.; Bolker, B.; Walker, S. Fitting Linear Mixed-Effects Models Using lme4. J. Stat. Softw. 2015, 67, 1-48. [CrossRef]

37. Wang, Y.; Naumann, U.; Wright, S.; Warton, D.I. mvabund: An R package for model-based analysis of multivariate data. Methods Ecol. Evol. 2012, 3, 471-474. [CrossRef]

38. Konietschke, F.; Placzek, M.; Schaarschmidt, F.; Hothorn, L.A. nparcomp: An R Software Package for Nonparametric Multiple Comparisons and Simultaneous Confidence Intervals. J. Stat. Softw. 2015, 64, 1-17. [CrossRef] 
39. Oksanen, J.; Blanchet, F.G.; Friendly, M.; Kindt, R.; Legendre, P.; McGlinn, D.; Minchin, P.R.; O’Hara, R.B.; Simpson, G.L.; Solymos, P.; et al. Vegan: Community Ecology Package, R Package Version 2.5-2. Available online: https://CRAN.R-project.org/package=vegan (accessed on 28 December 2019).

40. Korsós, Z.; Lazányi, E. Millipede fauna of Hungary: Present status. In Proceedings of the 18th International Congress of Myriapodology, Program and Abstracts, Budapest, Hungary, 25-31 August 2019; p. 42.

41. Kime, R.D.; Enghoff, H. Orders Polyxenida, Glomerida, Platydesmida, Siphonocryptida, Polyzoniida, Callipodida, Polydesmida. In Atlas of European Millipedes (Class Diplopoda); Pensoft Publishers: Sofia, Bulgaria, 2011; Volume 1.

42. Kime, R.D.; Enghoff, H. Atlas of European millipedes 2: Order Julida (Class Diplopoda). Eur. J. Taxon. 2017, 346. [CrossRef]

43. Bogyó, D.; Magura, T.; Simon, E.; Tóthmérész, B. Millipede (Diplopoda) assemblages alter drastically by urbanization. Landsc. Urban Plan. 2015, 133, 118-126. [CrossRef]

44. Enghoff, H. Diplopoda and Chilopoda from suburban localities around Copenhagen. Vidensk. Meddel. Dansk Naturhist. Foren. Kjøbenhavn. 1973, 136, 43-48.

45. Enghoff, H.; Pedersen, J.; Thomsen, P.F.; Iversen, L. Tusindben, skolopendre og mejere fra Rødbyhavn og omegn-med fem nye arter for den danske fauna (Diplopoda, Chilopoda, Opiliones). Entomol. Medd. 2011, 79, 3-12.

46. Kocourek, P. Mnohonožky (Myriapoda: Diplopoda) Prahy [Millipedes (Myriapoda: Diplopoda) of Prague (Central Bohemia)]. Nat. Prag. 2013, 21,3-146.

47. Korsós, Z. Millipedes from anthropogenic habitats in Hungary. Ber. Naturwiss. Med. Ver. Innsb. 1992, 10, 237-241.

48. Korsós, Z.; Hornung, E.; Szlávecz, K.; Kontschán, J. Isopoda and Diplopoda of urban habitats: New data to the fauna of Budapest. Ann. Hist. Nat. Musei Natl. Hung. 2002, 94, 193-208.

49. Riedel, P.; Navrátil, M.; Tuf, I.H.; Tufová, J. Terrestrial isopods (Isopoda: Oniscidea) and millipedes (Diplopoda) of the City of Olomouc (Czech Republic). In Contributions to Soil Zoology in Central Europe III, Proceedings of the 9th Central European Workshop on Soil Zoology, České Budějovice, Czech Republic, 17-20 April 2007; Pižl, V., Ed.; Institute of Soil Biology, Biology Centre, Academy of Sciences of the Czech Republic: České Budějovice, Czech Republic, 2009; pp. 125-132.

50. Smith, J.; Chapman, A.; Eggleton, P. Baseline biodiversity surveys of the soil macrofauna of London's green spaces. Urban Ecosyst. 2006, 9, 337-349. [CrossRef]

51. Stoev, P. Myriapoda (Chilopoda, Diplopoda) in urban environments in the City of Sofia. In Ecology of the City of Sofia. Species and Communities in Urban Environment; Penev, L., Niemelä, J., Kotze, D.J., Chipev, N., Eds.; Pensoft: Sofia, Bulgaria, 2004; pp. 299-306.

52. Tischler, W. Asseln (Isopoda) und Tausenfüßer (Myriopoda) eines Stadtparks im Vergleich mit der Umgebung der Stadt: Zum Problem der Urbanbiologie. Drosera 1980, 1, 41-52.

53. Vilisics, F.; Bogyó, D.; Sattler, T.; Moretti, M. Occurrence and assemblage composition of millipedes (Myriapoda, Diplopoda) and terrestrial isopods (Crustacea, Isopoda, Oniscidea) in urban areas of Switzerland. Zookeys 2012, 176, 199-214. [CrossRef] [PubMed]

54. Bachvarova, D.; Doichinov, A.; Abdulova, R. Seasonal activity of Leptoiulus trilineatus (C.L. Koch, 1847) and Megaphyllum trassylvanicum (Verhoeff, 1897) (Diplopoda: Julida: Julidae). Acta Sci. Nat. 2018, 5, 86-95. [CrossRef]

55. Mwabvu, T. Spirostreptid millipedes (Diplopoda, Spirostreptida) of urban and peri-urban habitats in Zimbabwe. Afr. J. Ecol. 2007, 45, 311-314. [CrossRef]

56. Nagy, D.D.; Magura, T.; Horváth, R.; Debnár, Z.; Tóthmérész, B. Arthropod assemblages and functional responses along an urbanization gradient: A trait-based multi-taxa approach. Urban For. Urban Green. 2018, 30, 157-168. [CrossRef]

57. Fournier, B.; Gillet, F.; Le Bayon, R.C.; Mitchell, E.A.D.; Moretti, M. Functional responses of multitaxa communities to disturbance and stress gradients in a restored floodplain. J. Appl. Ecol. 2015, 52, 1364-1373. [CrossRef]

58. Van Dyck, H.; Baguette, M. Dispersal behaviour in fragmented landscapes: Routine or special movements? Basic Appl. Ecol. 2005, 6, 535-545. [CrossRef]

59. Woodcock, B.A.; Pywell, R.F. Effects of vegetation structure and floristic diversity on detritivore, herbivore and predatory invertebrates within calcareous grasslands. Biodivers. Conserv. 2009, 19, 81-95. [CrossRef] 
60. Jokimäki, J.; Kaisanlahti-Jokimäki, M.-L. Spatial similarity of urban bird communities: A multiscale approach. J. Biogeogr. 2003, 30, 1183-1193. [CrossRef]

61. Magura, T.; Lövei, G.L.; Tóthmérész, B. Does urbanization decrease diversity in ground beetle (Carabidae) assemblages? Glob. Ecol. Biogeogr. 2010, 19, 16-26. [CrossRef]

62. Mori, A.S.; Ota, A.T.; Fujii, S.; Kabeya, T.S.D.; Okamoto, T.; Ito, M.T.; Kaneko, N.; Hasegawa, M. Biotic homogenization and differentiation of soil faunal communities in the production forest landscape: Taxonomic and functional perspectives. Oecologia 2015, 177, 533-544. [CrossRef] [PubMed]

63. McKinney, M.L.; Lockwood, J.L. Biotic homogenization: A few winners replacing many losers in the next mass extinction. Trends Ecol. Evol. 1999, 14, 450-453. [CrossRef]

64. David, J.F.; Handa, I.T. The ecology of saprophagous macroarthropods (millipedes, woodlice) in the context of global change. Biol. Rev. 2010, 85, 881-895. [CrossRef]

65. Golovatch, S.I.; Kime, R.D. Millipede (Diplopoda) distributions: A review. Soil Org. 2009, 81, 565-597.

66. Magura, T.; Horvath, R.; Tóthmérész, B. Effects of urbanization on ground-dwelling spiders in forest patches, in Hungary. Landsc. Ecol. 2010, 25, 621-629. [CrossRef]

67. Hornung, E.; Kásler, A.; Tóth, Z. The role of urban forest patches in maintaining isopod diversity (Oniscidea). ZooKeys 2018, 801, 371-388. [CrossRef]

68. Magura, T.; Hornung, E.; Tóthmérész, B. Abundance patterns of terrestrial isopods along an urbanization gradient. Community Ecol. 2008, 9, 115-120. [CrossRef]

69. Magura, T.; Tóthmérész, B.; Lövei, G.L. Body size inequality of carabids along an urbanisation gradient. Basic Appl. Ecol. 2006, 7, 472-482. [CrossRef]

70. Pouyat, R.V.; Szlavecz, K.; Yesilonis, I.D.; Groffman, P.M.; Schwarz, K. Chemical, Physical, and Biological Characteristics of Urban Soils. In Urban Ecosystem Ecology; Aitkenhead-Peterson, J., Volder, A., Eds.; Agronomy Monograph 55; American Society of Agronomy, Crop Science Society of America, Soil Science Society of America: Madison, Wisconsin, WI, USA, 2010; pp. 119-152. [CrossRef]

71. Alexandrovskaya, E.I.; Alexandrovskiy, A.L. History of the cultural layer in Moscow and accumulation of anthropogenic substances in it. Catena 2000, 41, 249-259. [CrossRef]

72. Craul, P.J.; Klein, C.J. Characterization of streetside soils of Syracuse, New York. Metria 1980, 3, 88-101.

73. Enghoff, H. The size of a millipede. Ber. Naturwiss. Med. Ver. Innsb. 1992, 10, 47-56.

74. Keddy, P.A. Assembly and response rules: Two goals for predictive community ecology. J. Veg. Sci. 1992, 3, 157-164. [CrossRef]

75. Kula, E.; Lazorík, M. Centipedes, millipedes, terrestrial isopods and their relationships to physical and chemical properties of forest soils. Entomol. Fennica 2016, 27, 33-51. [CrossRef]

76. Branquart, É.; Kime, R.D.; Dufrêne, M.; Tavernier, J.; Wauthy, G. Macroarthropod-habitat relationships in oak forests in South Belgium. 1. Environments and communities. Pedobiologia 1995, 39, 243-263.

77. Owojori, O.J.; Reinecke, A.J.; Voua-Otomo, P.; Reinecke, S.A. Comparative study of the effects of salinity on life-cycle parameters of four soil dwelling species (Folsomia candida, Enchytraeus doerjesi, Eisenia fetida and Aporrectodea caliginosa). Pedobiologia 2009, 52, 351-360. [CrossRef]

(C) 2019 by the authors. Licensee MDPI, Basel, Switzerland. This article is an open access article distributed under the terms and conditions of the Creative Commons Attribution (CC BY) license (http://creativecommons.org/licenses/by/4.0/). 